\title{
Issue of Waqf in the Context of Establishment of Muslim Institutions in the Post-Soviet Tatarstan
}

\author{
Azat M. Akhunov ${ }^{1}$ \\ ${ }^{1}$ Kazan (Volga Region) Federal University, Kazan, Russia \\ Correspondence: Azat M. Akhunov, Kazan (Volga Region) Federal University, 420008, Kazan, Kremlyovskaya \\ Street 18, Russia. E-mail: aakhunov@rambler.ru
}

Received: June 2, 2015 Accepted: June 15, 2015 Online Published: June 29, 2015

doi:10.5539/jsd.v8n5p157

URL: http://dx.doi.org/10.5539/jsd.v8n5p157

\begin{abstract}
The importance of the issue under study is specified by the increasing significance of the religious factor in the social and political, religious and cultural life of global community and Russia in the $21^{\text {st }}$ century. The aim of the article is to find out and analyze the tendencies of the development of Waqf system among Tatars at the end of the $20^{\text {th }}$ and at the beginning of the $21^{\text {st }}$ centuries, to determine the possibilities of religious institutions' financing by means of engaging and adapting such traditional instruments as Waqf to the modern conditions. The main method of the research is historical and comparative method, at the example of successful existence of Waqf property in the Russian Empire until 1917. Previous experience is compared with the modern state in the realities of the current Russian legislation. The article highlights the impossibility of the unimpaired operation of Waqf institution in the framework of available legal base and in the conditions of secular state. Alongside with this there offered ways of legitimization of separate principles of Waqf institution in the framework of current Russian legislation. The article presents the results indicating historical experience of the functioning of Waqf among Tatar in the past, rather successful existence of Waqf in the sovereign Tatarstan in the 1990s in the framework of local legislation, as well as failed attempts of the local authorities to solve the issue of Waqf property in the federal and all-Russia level. The article materials might be useful in the further study of institutional history of Russian Islam, as well as in modern social discussions about the role of religion in the secular space, and also in forming scientific and methodological, regulatory and legal framework to improve government policy about religion.
\end{abstract}

Keywords: Waqf, Muslim Spiritual Board of Tatarstan, Tatarstan Republic, religious organizations funding

\section{Introduction}

It is known that Waqf (Arabic. "Retention") - is an inalienable and a non-taxable property withdrawn from the circulation and bequeathed to religious and charitable purposes, providing material assistance, as well as in support of Islam. For centuries, Waqf had always been the only regular source of funding for higher education in the Muslim world. Proceeds from the Waqf were received not only by the schools, teachers and students, but also by the catering staff: cooks, barbers, watchmen and others (Bekkin, 2008).

As for Tatars, information given by a scientist Aydar Habutdinov proves that most of Awqaf in the Volga region was immediately eliminated after the conquest of Kazan Khanate by Moscow, and finally the process was completed in the last years of the Empress Anna Ioannovna (1730s.) (Khabutdinov, 2013). Waqf increase in the region started again in the second half of XIX century. According to historians Ramil Khairutdinov and Radik Salihov "Before the Revolution (October Revolution of 1917 - AA) in Kazan all 17 mosques of the city had their own Waqf property transferred to them by philanthropists in perpetuity. These were a profitable multi-family residential, shops, plots, finances invested in a number of banks, the interest income of which uninterruptedly financed the church, the parish madrassas, mullahs and muezzins and mugallims. Therefore, almost all of Kazan Mahallas being considered quite rich associations with solid cash accounts and expensive real property in the absence of state support determined the fact of their own existence"(Khairutdinov and Salihov, 2004).

Activities of Awqaf among Tatars stopped almost immediately after the 1917 revolution, in contrast to Turkestan, where this traditional institution for Muslim community continued to operate until the mid-1920s (Pianciola and Sartori, 2007). 
In general this issue is not sufficiently developed, the same is true for Islamic studies in the West, which had been focusing on the issue of Waqf only in the last two decades (Hoexter, 1998; Çizakca, 1998). The greatest emphasis is placed on research of the historical Waqf, the present situation is not studied well.

In the view of all this, there is an increasing interest to study the situation with Waqf in modern Russia. Namely, in one of the leading Muslim regions of the country in the Republic of Tatarstan. It is quite essential to answer the question whether the republic succeeded in reviving Waqf system and adapted it to the modern realities for 25 years history of its post-Soviet development. According to this the positions of religious authorities, representatives of the top political circles, Tatar intellectuals play significant role.

The revival of Waqf system is impossible without corresponding changes in the legislative sphere, which is not yet ready to meet even insignificant concessions about long-felt needs of its Muslim citizens. It is all the same with Islamic banking, the support and development of which might to some extend enliven Russian economy under the current sanctions from western financial institutions. If there is an action towards this direction, there is still no action towards Waqf.

\section{Methodological Framework}

Democratic changes that took place in Soviet society in the mid-1980 s. caused deterioration in religious life. By the end of 1990 there were two official religious structures in Tatarstan, both of which laid a claim to lead the spiritual realm: founded in 1992, MSB RT (Muslim Spiritual Board of Tatarstan Republic), headed by Gabdulla Galiullin and MSB T (Muslim Spiritual Board of Tatarstan), where in 1997 Farid Salman was appointed as a head. The latter structure came into being on the basis of Central muhtasibat management of Tatarstan in 1994, and was ruled by CMSB (Central Muslim Spiritual Board of Russia and European CIS countries), headed by Talgat Tadzhutdin.

At that time, both organizations controlled approximately 350 Muslim parishes of the republic, but just the leader of the MSB RT Gabdulla Galiullin had the real power in his hands. MSB RT managed to organize three Congresses, two of which were held in 1992 and one was dated to 1995. Last forum, conceived and implemented as a unifying one, had not really led to the desired results, but only deepened the split. The continuing confrontation between rival muftiats splashed into scandals at a federal level. Unpredictable and uncoordinated actions by Mufti Gabdulla Galiullin damaged the reputation of the country, which had always been positioned as a region where there were no problems between different ethnic groups and faiths. Thus, it was quite an understandable desire when state authorities wanted to work with a loyal body and it led to the fact that the questions about a new leader of Muslims of Tatarstan, and about a Republican muftiat appeared on the agenda.

A unifying congress of Muslims seemed to be the only form of legitimization of this idea, and the preparation under the supervision of the President of Tatarstan Mintimer Shaimiev began (Akhunov, 2014).

\section{Results}

The Unifying Congress of Muslims of Tatarstan with the support of the authorities was held in February 1998. As a result of the decisions made only the Muslim Spiritual Board of Tatarstan was allowed as a single muftiat (MSB RT).

Waliullah Hazrat Yakupov at this Congress was elected as the first deputy mufti and became a Chairman of Awqaf. Thus, in the Muslim Spiritual Board of Tatarstan a special person responsible for all the issues related to Waqf property appeared.

Tandem of the state and religion led to the stabilization of the situation, and made it possible to lead a quiet and effective work in the scope of religion. Muslim parishes management system was created, the MSB RT structure was formed (Pilkington, H. \& Yemelianova G. (Eds.), 2003), an extensive educational network for various grade levels appeared. Number of the parishes united around the mosque had increased into thousands. By 2002 there were a Russian Islamic University, 2 higher madrasas, 6 secondary Muslim madrasas and 1 high school in Tatarstan (Materialy, 2002).

By the II-nd Muslims Congress (2002), it became clear that maintaining the whole system in operating state requires huge financial investments. Muslims of Tatarstan could only rely on the donations of parishioners, individual sponsors and patrons, episodic tranches from the local budgets, which, of course, could not solve the problem.

This concern was pointed out in a speech of mufti Gusman Iskhakov at the Heads Congress of MSB RT. For example, only to cover the cost of utilities for mosques maintainance required 10 million rubles per year. The only way out indicated by the head of the Muslim Spiritual Board was in the practical implementation of Article 
18 of the Law of the Tatarstan Republic adopted in 1999: "On Freedom of Conscience and Religious Associations", which included an item on the rights of religious organizations to own a Waqf property and the fact of its inalienability (Materialy, 2002).

Also the first deputy mufti, chairman of Awqaf Waliullah Yakupov gave a speech at the convention, who explained the use of the law in favor of the Muslims in details. It was known that de facto the Waqf property had already been existing in the center of Kazan: a series of buildings and facilities had been transferred to the use of Muslims, but contradicting the federal law its state continued being uncertain (Materialy, 2002). Particularly vividly it appeared on the background of the just started active process of bringing regional laws into the very line with federal regulations.

Leaders of Muslims of Tatarstan had no choice but to make a proposal to the State Duma showing the importance of the Waqf property legalization in the federal law "On Freedom of Conscience and Religious Associations." Theoretically the existing law allowed religious organizations to have different kinds of movable and real property, protected it from the penalties of creditors, but it just reflected the property of liturgical purposes. The Waqf property wasn't of the same origin (for example, buildings, rental properties for offices, etc.), i.e. one of the basic principles of the Waqf that is its inalienability was violated.

It was also suggested to use ongoing Article 582 of the Civil Code of the Russian Federation ("Donations"), which, according to the first deputy mufti, "practically legalizes awkaf (Endowments) in the form of donations, i.e. the donor is given certain powers in the field of the further fate of the donated property, might follow its intended use, etc. and even in the case of misuse the donor might claim restitution "(Materialy, 2002).

The VII All Russia research and training conference of CEOs of Muslim Spiritual Board, held in June, $14^{\text {th }} 2004$ in Kazan, was the venue to raise the issue about Waqf again. The chairman of the religious affairs committee at the Cabinet Council of Tatarstan Republic Rinat Nabiev drew the attention of the audience to the fact that the ally of religious organizations in establishing and developing of endowment must be the government of the country. Due to this partnership and the existence of local law "On the freedom of conscience and religious associations" with the corresponding regulations about Waqf, almost $90 \%$ of endowment was given back to Muslim communities (Saiganova, 2004). The other side of the issue is that many of these buildings were not used and therefore didn't bring any profit.

Moreover, during the discussions it was pointed out that many Muslim spiritual leaders didn't understand the purpose of Waqf. They forgot that endowment couldn't be owned by religious organizations. They can use only the profit that endowment brought (Bekkin, 2004).

Further along, to solve the problem of Waqf, local secular authorities appealed to Federal officials, explaining this as worrying about local and "traditional" Islam. For instance, during the meeting, held in November 2006, with the Plenipotentiary Envoy of Russian President in Volga Federal District Alexander Konovalov, presidential advisor of Tatarstan Rafael Khakimov offered to pass legislation about Waqf institution in Russia, which might "provide self-financing of Muslim community and reduce its dependence on foreign sponsors". During this meeting the chairman of the religious affairs committee at the Cabinet Council of Tatarstan Republic Rinat Nabiev reported that the government of Tatarstan Republic is considering the issue of giving a loan of 10 million roubles to Waqf institution, which indicated to the government's direct interference to the religious affairs (Kirillovich, 2006).

Tatarstan officials' reluctance to lose local version of the Law "On the freedom of conscience and religious associations" was the local elite's attitude to the Federal centre, wish to preserve the sovereignty of Tatarstan, which after coming President Vladimir Putin to power had shrunk so much. The fact that Tatarstan positioned itself as the engine of progressive ideas, reforms and innovations for the whole Russia promoted that shrink. If they could preserve the article on Waqf in the local legislation, it could have been transferred to the Federal Law. If everything went all right, and this plan would have been realized, Tatarstan might have gotten enough image incentives as a protector of Muslims in Russia. The law on Waqf in case of its realization might not solve financial problems of religious organizations, but bring more moral dividends.

As a result, in February 2008 the prosecutor of Tatarstan Republic Kafil Amirov protested local regulations on Waqf, because there was nothing about it in Federal legislation. Tatarstan President Mintimer Shaimiev had to amend the law. Regulations for endowment were preserved but they would be regulated by Federal legislation (Minin, 2008). So the decision which de facto ceased the Republican regulations on Waqf to be effective was taken.

The Republic still used nonconforming Federal legislation local law on religious organizations, but it was 
counterproductive to rely on it, especially under the terms of reinforcement of vertical power structure.

Under this condition local officials sought the way out of this situation. In February, 2008, after the protest of Tatarstan prosecutor, mufti of Muslim Spiritual Board of Tatarstan Republic Gusman Iskhakov sent a letter to the vice-president of Russia, chair of the committee on the issues of religious associations Dmitry Medvedev. In this letter he pointed out the importance of Waqf for the development of religious institution and charities of Muslim organizations, saying that introduction of this norm would help escape the influence of foreign charities. Particularly, he pointed out that "many of them (Islamic organizations - A.A.) decided to use foreign charity funds and became involuntary victims of foreign religious ideology. Knowing this, religious communities start to refuse such collaboration, and the issue of financial sufficiency becomes relevant".

Tatarstan mufti offered to amend Federal Law "On the freedom of conscience and religious associations" and add the notion of "endowment", exempting it from taxation as the real estate for religious and liturgical purpose.

According to further events, this letter didn't make any sense and everything was left as it was (Mufti Iskhakov, 2008).

In June, $18^{\text {th }}$ of the same year, the chair of the committee on culture, science, education and national issues of Tatarstan Parliament Razil Valeev announced that Tatarstan State Council intends to offer the introduction of the notion of "endowment" to Russian Federal legislation. According to him, "in all Islamic world, e.g. in Saudi Arabia or Turkey, endowment is natural phenomenon. There shouldn't be different approaches to Islam in different countries". Valeev also stated that the profit from Waqf "might be used for religious needs, so there shouldn't be any taxation of the endowment" (Minin, 2008).

This initiative was sent to the corresponding body of government, but officials in the name of Ministry of Finance of Russia gave standardized response "the issue of Waqf of religious organizations is not regulated in legislation".

Expert on Islamic Law, Doctor of Legal Science Leonid Sykiainen gave an answer to the proposal of Razil Valeev. He pointed out that he had no wish to introduce the notion of "Waqf" to Russian Federal legislation. As, "it will be rather difficult, considering the fact of establishment of Russian legislation, regulating the issue of ownership".

On Sykiainen's point of view "Russian legislation on the Federal as well as Republican levels allows to realize actions that are close in their content and don't differ principally from those as Waqf'. Waqf institution has never been linked only with the religious organizations and does not assume the expenditure only for the religious purpose (Sykiainen, 2008)

Various organizations and individuals try to speculate at the issue of Waqf between 1990s and 2000s. So, in April, 1997 civil society organization "Waqf" of Tatarstan Republic was registered in Kazan, which aim was to work as religious organization, deal with construction and organizing part-time residence. The fact that it was co-founder of the Fund of financial support for reconstruction, restoration and development of al-Mardzhani mosque complex says that "Waqf" of Tatarstan Republic was in the purview of the distinguished religious figure imam-mukhtasib of Kazan and imam of Mardzhani mosque Mansur Dzhalyaletdinov, who tried to put his name forward to become Mufti of the Spiritual Board of Muslims of Tatarstan Republic, though not successfully (Vypiska, 29.09.2014).

Fund "Waqf Idel", located in the same address as Mardzhani mosque, started functioning in November, 2003. According to official documents its founders were Muslim Spiritual Board of Tatarstan Republic and mufti Gusman Iskhakov. Core activities of the Fund were financial assets (placement), social services without providing accommodation (housing allowances, aid to refugees and etc.), non-political social organizations, sport events (organizing, preparation and realization). Since 2012 Fund collaborates with endowment fund "Idel-Hajj" to attract financial resources and investment of the potential pilgrims' finances to different projects that are allowed by Islam (Nakopitel'ny fond, 2012).

Another fund under the name "Waqf Kazan" was registered in July, 2011. Core activities of the Fund are to provide social services with accommodation, work of libraries, archives, club type institutions and other financial intermediary. One of the founders was ex-mayor of Kazan Kamil Iskhakov's daughter Tereza Kamalova, who actively participates in organizing different Muslim cultural and educational events (Vypiska, 30.09.2014).

Though, official fund "Waqf", which could cooperate in the name of Muslim Spiritual Board of Tatarstan Republic with the government, was established only in January, 2009. As from the date of its opening core activities were declared as follows as search of investors to build the projects which would be useful for Muslim 
organizations of Tatarstan, also legal confirmation of transfer of land property and buildings by Waqf. The management board of the organization consisted of 10 members (including those with theological education), who could make decisions on issues concerning the activities of Waqf, as the usage and distribution of resources, received from commercial Waqf (Murat Galeev, 2009).

In the year of "Waqf" establishment government gave the organization two land properties and one building from private citizen. In Kurban-bayram (Id al-Adha) of 2010 manager of the organization Murat Galeev (business partner of mufti Gusman Iskhakov) presented the complex to slaughter animals "Kurban-bayram", situated in Brat'ev Petryaevyh street, Kazan (total area of 10280 square meters was transferred for free use by the executive board of Kazan). "Waqf" planned to open similar complexes in the other districts of the Republic (Postanovlenie ispolnitel'nogo komiteta, 2009).

In spite of first active actions, during the $4^{\text {th }}$ meeting of Muslim Spiritual Board of Tatarstan Republic in February, 2010, President of Tatarstan Republic Mintimer Shaimiev in his speech criticized the managers of Spiritual Board, who established "Waqf", which founders were only private individuals. The founders staff must have annoyed the President, because among founders there were "suspicious" imams as Shavkyat Abubakerov, Ramil Yunusov, Rustam Zinurov and others, graduates of Saudi and local religious institutions and very popular religious leaders in Tatarstan, who attracted a lot of young people to their sermons and who had independent behaviour.

Certain suspicion was caused by the fact that officially fund "Waqf" was registered as "local Muslim religious organization" which according to the Law "On the freedom of conscience and religious associations" could establish separate Spiritual Board, joining with two other structures alike. And further events showed that the suspicions were not groundless.

On President Shaimiev's point of view, which was given in the meeting, fund must be under the control of Muslim Spiritual Board of Tatarstan Republic and work for all Muslim ummah. It was declared that "every Muslim must know that his share is used on purpose, and not got to somebody's pocket". Also in his speech President told about inefficient usage of buildings transferred to the Muslim Spiritual Board of Tatarstan Republic (19 out of 42 were not used, particularly historical building of former Muslim asylum, which was transferred by the government in 2006) (V dvizhenii - uspeh (success is in movement), 2010).

Fund "Waqf" lost support with the termination of power of the chairman of Muslim Spiritual Board of Tatarstan Republic Gusman Iskhakov in January, 2011. In April, 2012 the manager of "Waqf" Murat Galeev tried to register alternative Muslim Spiritual Board, joining with two Muslim organizations of Tatarstan (parish of "Anilar" mosque in Kazan and parish of "Azan" mosque in the village of Russkiy Aktash, Almet'evsky district of Tatarstan Republic), but soon recalled corporate establishment documents from the Ministry of Justice in Tatarstan (Antonov, 2012).

Recently he lost the case to the municipal institution "Committee for land and property relations of the executive board of municipal establishment of Kazan" about the free usage transfer of the buildings in Kazan with total area of 410,4 square meters and compensation of expenses for the repair. The point was that in April, 2009 "Waqf" rented these buildings to open Muslim café, which was not opened. "Waqf" relying on the Federal Law 125 "On the freedom of conscience and religious associations", demanded these buildings to be transferred on free use. The reason was that tenant held some religious rituals there and this made these buildings for the religious purpose. Executive Board of Kazan, arbitration court and courts of appeal didn't agree with the reason and disputable buildings remained as the government property (Federal, 2011).

Later, in July 2012, manager of "Waqf" fund was arrested as a suspect in case of assassination attempt to Tatarstan mufti Ildus Faizov and killing of the chief of educational department of Muslim Spiritual Board of Tatarstan Republic Waliullah Yakupov.

New team of Muslim Spiritual Board of Tatarstan Republic in November, 2011 re-established fund "Waqf of Tatarstan Republic" (Utchrezhden Fond, 2012). In this case Muslim Spiritual Board of Tatarstan Republic was the main founder, but it was supposed that it would develop autonomously.

It was declared that the main aims of fund would be the following: formation and usage of material and financial resources on the voluntary basis, pursuing the social, charity, cultural, educational and other valuable aims in the sphere of Muslim religious organizations.

The work of fund is to determine prior trends of providing object-oriented help to Muslim religious organizations, including Muslim spiritual educational institutions, also Children's Muslim institutions, certain financially disadvantaged citizens, who need social and material support, assistance in security, repair, 
restoration of buildings, constructions of cultural and charity and other purposes, organization and participation in realizing the projects financed by the fund.

Core activities are recreation of the existed system of unalienable property in Tatarstan Republic - Waqf, establishment of united register of real estate record (registered and non registered), which is used by Muslim Spiritual Board of Tatarstan Republic; registration of real estate for ownership of Muslim Spiritual Board of Tatarstan Republic; development of benevolence with the partners, participating in charity, together with the Muslim Spiritual Board of Tatarstan Republic work out concept of development on usage of real estate to create economical bases of self-repayment of maintenance of religious organization structure; participation in competitions and grants organized by Tatarstan Republic and Russian Federation to get subsidies from budget to finance the projects; creation of mechanisms of effective management, exploitation, repair and maintenance of the real estate that are used by Muslim Spiritual Board of Tatarstan Republic.

Despite the great number of aims and activities declared, new fund "Waqf of Tatarstan Republic" didn't approve itself, didn't have any large-scale actions or events. Therefore it is difficult to say about its activities and efficiency.

\section{Discussions}

Thus, we observe that over the 1990-2000's Muslim leaders of Tatarstan, in conjunction with government agencies tried to build a Waqf institution in the country. Muslim organizations have been allocated to use land, real estate as Waqf, and financial help in the form of loans. Legitimacy of all these actions was put into question because of non-compliance of local laws with federal ones.

All the initiatives to amend the relevant federal law were rejected. Information about buildings, lands transferred to the possession of Muslims and incomes from the very operations remains closed. The loss of property occurs because of the absence of clearly registered Waqf buildings, which has no legal status at all. All these problems require the most immediate solution and manifest the fact that in a secular state institutionalization of the Waqf system is practically impossible.

\section{Conclusions}

The issue of legitimization of Waqf in the framework of Russian legislative environment requires urgent steps. The discussion of the issue in Muslim ummah is also increasing every year. The reason of this at first is volatile situation with the absence of reliable sources of funding Muslim infrastructure. Under the conditions of inpayment reduction from the benefactors and charity providers, who have some difficulties amid the crisis in economics, the Muslims have to rely on their own resources only. The full and official use of Waqf institution, if not reduce the tension, might ease the situation of Muslim organizations.

As it was mentioned above, the outcome of the situation might be the adaptation of Russian laws and regulatory acts for the legitimized usage of properties like Waqf. It refers not only to Muslims but to Orthodox Church as well, to the representatives of other traditional religions in Russia, non-sectarian citizens and enterprises. In this case, noting common interests including non-religious organizations, little correction of Russian legal bases might be enough.

And it is not necessarily to say about religious nature of amendments, but as mandatory position in the framework of civic rights, take into consideration these or those features peculiar to the confessions. For instance, the issue of inalienability of the property in Islam. In such way government preserves the principle declared by the Russian Constitution, which says that "religious communities are separated from the government and are equal before law".

\section{Acknowledgments}

The work is performed according to the Russian Government Program of Competitive Growth of Kazan Federal University.

\section{References}

Akhunov, A. M. (2014). Russia-Middle East: The Influence of the Arab Factor on the Formation of Muslim Education System in the Republic of Tatarstan in 1990-2000. Terra Sebus. Acta Musei Sabesiensis, 135-146.

Antonov, K. (2012, April 10). DUM gotovyat al'ternativu. V respubliki sozdayut vtoroi muftiyat. Kommersant-Volga-Ural.

Bekkin, R. (2004, August 18). Tysyacha somnitel'nyh dinarov. Nezavisimaya gazeta - religii. 
Bekkin, R. I. (2008) Institut wakfa v social'no ekonomicheskoi I politicheskoi zhizni musul'manskih stran. Vestnik Sankt-Peterburgskogo Gosudarstvennogo universiteta, 3, 105-114.

Çizakca, M. (1998). Awqaf in History and Its Implications for Modern Islamic Economics. Islamic Economic Studies, 6(1), 45-70.

Federal'nyi arbitrazhnyi sud Povolzhskogo okruga. Postanovlenie ot 6 May 2011 y. Delo \# A 65-18731/2010 (2011). Elektronnyi fond pravovoi I normativno-tehnicheskoi dokumentatsii. Retrieved September 25, 2014, from http://docs.cntd.ru/document/917034940.

Hoexter, M. (1998). Waqf Studies in the Twentieth Century: The State of the Art. Journal of the Economic and Social History of the Orient, 41(4), 474-495. http://dx.doi.org/10.1163/1568520001445568

Khabutdinov, A. Yu. (2013). Instituty Rossiiskogo musul'manskogo soobshchestva v Volgo-Ural'skom regione. Moskva: Izdatel'skii dom Mardzhani.

Khairutdinov, R., \& Salikhov, R. (2004). Wakuf: cherez proshloe - k budushchemu. Minaret, 3(3), 68.

Kirillovich, G. (2006, November 3). Musul'mane prosyat podderzhki. Kommersant-Volga-Ural.

Materialy Vtorogo Ocherednego s'ezda musul'man Tatarstana. (2002). Kazan: Iman.

Minin, S. W. v z. (2008, 2 July). Nezavisimaya gazeta religii.

Muftii Iskhakov predlozhil Medvedevu vvesti v pravovoi obihod ponyatie "wakuf". (2008, February 29). $\begin{array}{lllll}\text { Newsru.com. } & \text { Retrieved } & \text { September } & 25, & 2014,\end{array}$ http://www.newsru.com/arch/religy/29feb2008/wakf.html

Murat Galeev: Wakf - dostoyanie vsego musul'manskogo obchestva. (2009, August 11). Islam-news. Retrieved September 27, 2014, from http://www.islamnews.ru/news-19943.html.

Nakopitelnyj fond "Idel Khadzh" - novye vozmozhnosti dlja sovershenija khadzha. (2012, June 20). Info-islam. Retrieved September 25, 2014, from http://www.info-islam.ru/publ/statji/nakopitelnyj_fond_idel_khadzh_novye_vozmozhnosti_dlja_sovershenij a_khadzha/5-1-0-15057

Pianciola, N., \& Sartori, P. (2007). Waqf in Turkestan: the colonial legacy and the fate of an Islamic institution in early Soviet Central Asia, 1917-1924. Central Asian Survey, 26(4), 475-498. http://dx.doi.org/10.1080/02634930802017929

Pilkington, H., \& Yemelianova, G. (Eds.). (2003). Islam in Post-Soviet Russia. Public and private faces. London and New York: Routledge Curzon.

Postanovlenie Ispolnitel'nogo komiteta municipal'nogo obrazovaniya goroda Kazani ot 29 sentyabrya 2009 g. \# 8211 "O predvoritel'nom mestnoi musul'manskoi religioznoi organizatsii - Prihodu "Wakf" Duhovnogo upravleniya Musul'man Respubliki Tatarstan mesta razmeshcheniya ob'ekta po ul. Brat'ev Petryaevyh". (2009). Elektronnyi fond pravovoi I normativno-tehnicheskoi dokumentatsii. Retrieved September 25, 2014, from http://docs.cntd.ru/document/917034940

Saiganova, S. (2004, April, 16). Musul'mane uchatsya upravlyat' tem, chto imeyut. Vremya I den'gi.

Sykiainen, L. (2008, July 2). Mezhdu nazvaniem I sut'yu. Nezavisimaya gazeta - religii.

Uchrezhd'en Fond "Wakf RT". (2012, January 11). Ofitsial'nyi sait Duhovnogo upravleniya musul'man Tatarstana. Retrieved September 25, 2014, from http://dumrt.ru/node/2238

V dvizhenii - uspeh. (2010, 5). Respublika Tatarstan.

Vypiska iz edinogo gosudarstvennogo reestra uridicheskih lits (EGRJUL). (2014, September 29). Ofitsial'nyi sait federal'noi nalogovoi sluzhby $R F$. Retrieved September 29, 2014, from http://egrul.nalog.ru/

Vypiska iz edinogo gosudarstvennogo reestra uridicheskih lits (EGRJUL). (2014, September 30). Ofitsial'nyi sait federal'noi nalogovoi sluzhby RF. Retrieved September 30, 2014, from http://egrul.nalog.ru/

\section{Copyrights}

Copyright for this article is retained by the author(s), with first publication rights granted to the journal.

This is an open-access article distributed under the terms and conditions of the Creative Commons Attribution license (http://creativecommons.org/licenses/by/3.0/). 